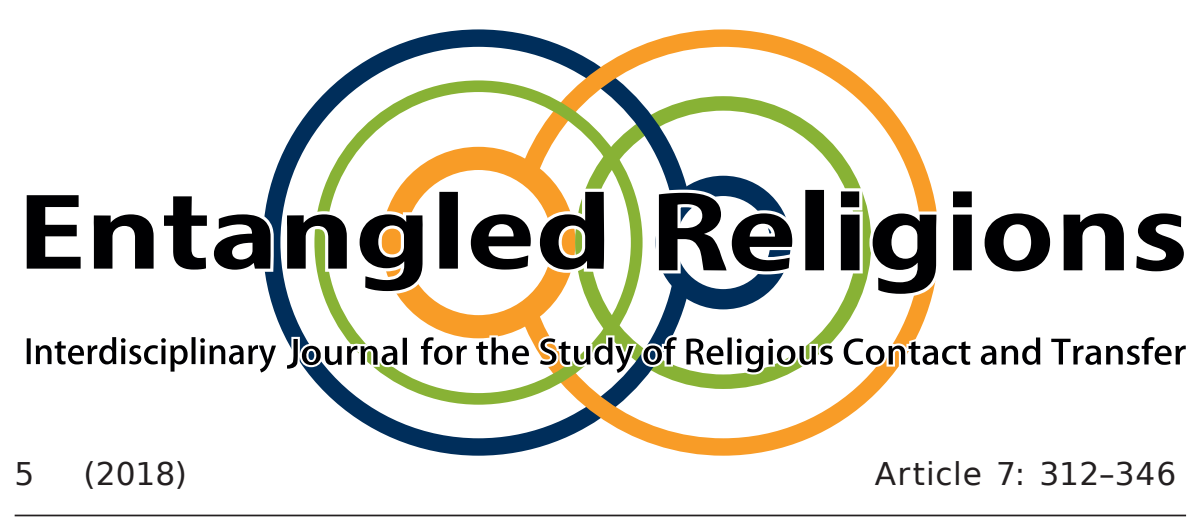

\title{
Acculturated Otherness. Christian Churches and Wedding Chapels in Modern Japanese Society
}

\section{BEATE LÖFFLER}

IN-EAST School of Advanced Studies, Universität Duisburg-Essen, Germany

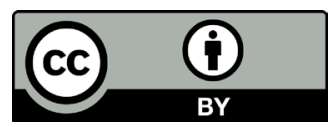

This contribution to Entangled Religions is published under the Creative Commons Attribution 4.0 International Public License (CC BY 4.0 International). The license can be accessed at https://creativecommons.org/licenses/by/4.0/legalcode.

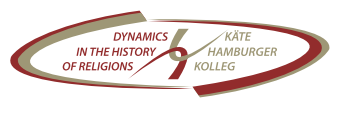

SPONSORED BY THE 


\title{
Acculturated Otherness. Christian Churches and Wedding Chapels in Modern Japanese Society
}

\author{
BEATE LÖFFLER \\ Universität Duisburg-Essen
}

\begin{abstract}
During the latter half of the nineteenth century, the Japanese government ended the centuries-long Japanese policy of isolation and initiated a rapid modernization effort that aimed to create a competitive Japanese nation state. In addition to such changes as new family law, compulsory education, and redistribution of property, the government contracted foreign experts with the goal of importing western knowledge. As a result, civil engineers, artists, and physicians started moving to Japan, as did missionaries. This resulted in intense cultural encounter and negotiation, in the course of which Christian faith and Western church architecture became acculturated in Japan. This article sketches the socio-cultural and technological parameters shaping Japanese Christian church buildings from the 1860s onwards as well as the transfer of meanings and forms from an explicitly Western tradition into a Western-looking and yet entirely Japanese tradition of Christianity. It sketches a second line of transfer as well, that reinterpreted the 'church' as an architectural form into the WeddingChapel-Romanticism of the non-Christian Japanese mainstream wedding industry.
\end{abstract}

KEY WORDS Japan; Christianity; popular culture; church architecture; mission; wedding chapel; acculturation

\section{Introduction}

During the second half of the nineteenth century, Japan was forced by western economic and diplomatic interests to end its previous isolationist policy and to play a greater role in the East Asian region. Having learned lessons from China's experience, the government tried to prevent 
colonisation by initiating a complex process of modernization. It introduced an administrative apparatus and technological and cultural knowledge from the West, ${ }^{1}$ dispatched students to renowned educational institutions abroad, and hired experts from Europe and North America as advisers and teachers. As a result, the respective knowledge about the other culture soon grew extensively in both regions, not only in terms of textual sources but in terms of artefacts and visual sources as well. At the same time, western social practices were adopted by some parts of Japanese society, while building technologies and architectural forms became part of the Japanese built environment, as did-over time-Christian churches.

The research project presented here analyses the development and acculturation of Christian church architecture in Japan with regard to design, construction, placement within the urban environment, attribution of meaning, and perception by the Japanese Christian minority as well as by the non-Christian majority. It sketches the shift, from the 1860s onwards, from an explicitly western-and hence foreign—set of forms and meanings towards two strictly Japanese variations of appropriated otherness, the Christian community church and the Japanese wedding chapel (Löffler 2011, 2018, 2019).

By the phrase 'acculturated otherness', I mean a balance between adopting a hitherto unknown or uncommon cultural phenomenon and consciously or unconsciously preserving symbolic patterns that mark a significant difference from the perceived social majority or the experienced everyday culture. While this might well take the form of a practice or the

1 The term 'the West' or 'western' comprises the hegemonic nation-states of the time which sought to establish relationships to Japan, mainly the United States of America, the British Empire, France, the Russian Empire, the Netherlands and Prussia/the German Empire. 
use of special language or terminology, in this project the focus is on the (chosen) level of appropriation of architectural forms, outwards and inwards.

We will see two interrelated processes that are characterized by the intentional and non-intentional creation, adoption and preservation of tradition(s) in the meaning of a (perceived) continuity. The "handing down' involved actors from different cultural backgrounds and various interpretations, and even the artefacts themselves underwent changes; yet the whole process reads like the continuous weaving of a textile with changing patterns, yarns, or weavers: innovative and adaptive. In consequence, this case challenges the understanding of the term 'tradition' as explicated in the Käte Hamburger Kolleg Dynamics in the History of Religions Between Asia and Europe working paper on tradition (Krech and Karis 2017,1 ) by showing that the performative dimension of tradition is not entirely self-referential but might include outside referencing.

This essay reflects on the role of architectural artefacts in religious contacts and transfers. It aims to foster cross-disciplinary communication by developing a strictly inductive hermeneutical analysis of material culture towards the broader conceptual ideas of social interactions as pursued in today's religious studies.

The essay is based on extensive architectural field research of about 300 buildings, churches, and wedding chapels in Japan and the ensuing analysis in a context of architectural history. ${ }^{2}$ Thus, the technical data

2 A minority of the investigated churches was already published on in the context of architecture or heritage protection as significant and meaningful examples of Christian church buildings in Japan, most notably the churches in Nagasaki prefecture. The majority of cases were part of systematic samples taken in the central districts of eight Japanese cities. Of the 26 wedding chapels, about half were written about in diverse contexts of architectural discourse due to their architectural characteristics, the other half samples taken from the field. 
collected on site (descriptions, structural and formal analyses of facades and rooms; interior and equipment; measurements, sketches, photographs; oral and textual data about the buildings given by the communities orin case of the wedding chapels-bridal parlours) form the backbone of the investigation. It is reflected against textual and visual historical sources, such as mission reports, on the one hand, and on observations on the building's urban settings, on the other ${ }^{3}$ (Löffler 2011, 7-11). Building on this material, the essay aims to contextualize the observations within the broader frame of cultural and religious encounters, echoing the stimulating cross-disciplinary discussions at work at the Käte Hamburger Kolleg Dynamics in the History of Religions Between Asia and Europe at the Center for Religious Studies, Ruhr University Bochum.

I suggest reading the observed phenomena as evidence for an intrinsically heterogeneous transfer and acculturation of religion as a system of interwoven teachings and scriptures, practices and artefacts, customs and symbols. Further, I suggest understanding this heterogeneity as a means for a fruitful integration of an arriving religion into an existing cultural and religious environment.

\section{Historical Context}

The first era of European-Japanese contact and Christian mission in Japan, which started in 1549, was brought to an end in 1640 by the Tokugawa government through the prohibition and prosecution of Christian worship and the near total cutting off of foreign relations.

3 Interviews and participant observation were not intentionally planned but occasionally occurred. The resulting insights-contextualized by secondary literature-allowed for a more complex interpretation of the architectural artefacts. 
Following the (enforced) re-establishment of foreign relations during the 1850s, though religious regulations remained in effect, the earliest modern churches in Japan were erected within the extraterritorial settlements in Yokohama and Nagasaki in 1862 and 1864, respectively, to care for foreign Christians and to serve as religious landmarks. The buildings, in fact, attracted a lot of attention and became destinations for excursions by Japanese from the surrounding areas before the Japanese government stepped in to discourage this in an attempt to keep the Christian mission in check (Ballhatchet 2003; Jennes 1973, 229; Hecken 1963, 11-13). Despite limitations imposed on foreigners in general, and missionaries in particular, Christian culture managed to gain a foothold through conversions among Japanese employees of western businesses and students. While there was some academic interest in the schools of thought underlying the by then dominating western civilisations and the conscious adoption of the faith due to political considerations, lasting conversion usually rooted in close social interaction. Teachers and missionaries across all denominations served as examples of Christian morals and charity in their respective environment and inspired the development of small communities that gained momentum over time. ${ }^{4}$

This development was supported by international pressure to abandon restrictions on religious freedom. From the 1880s, at the latest, Christian communities and churches appeared in a number of places nationwide, the link to schools and charitable institutions remaining dominant. At the same time, Catholic missions in southern Japan focused strongly on the

4 One of these groups started in Yokohama and became the training ground of Reformed or Presbyterian churches, respectively. The fusion of Kumamoto Band and Niishima Jō formed the core of puritan training. The Sapporo Band was non-denominational and formed the ground from which Uchimura Kanzō‘s thoughts of an non-institutional Christianity grew (Oshiro 2007; Ballhatchet 2003, 44-45; Dumoulin 1990, 1380-1381; Iglehart 1959, 31, 5557; Kitagawa 1961, 7-9). 
re-integration of so-called 'Underground Christians' who had survived the persecution in rural Kyushu (Miyazaki 2003).

The heterogeneous development of the communities was reflected in the appearance of the first church buildings outside the extraterritorial settlements. The new churches of 'Underground Christians' were built in rural areas and were situated amongst farmer's houses-single-story wooden constructions adapted to the local materials and climate. The surviving churches show a hybridity of adjustments to their environment, on the one hand, and a conscious play with significantly churchlike forms, on the other, as we will see in more detail later. In most other places, the buildings were erected in urban contexts, as were railway stations, schools, industrial plants, administrative buildings, museums, and the like-all of which represented the modern functions and forms of a new era, deeply influenced by western models of technology and civilisation. The knowledge about these architectural solutions came with foreign advisers and entrepreneurs, Japanese students returning from abroad, and not least from books. All these new building types came with a complete set of features well known and immediately recognizable in occidental cultures and the western systems of visual codes. These features were adopted in Japan as ready-made spatial and formal solutions for contemporary demands but with varying degrees of hybridisation (Finn 1995; Stewart 2002).

It is difficult to estimate how far the physical transformation of the Japanese built environment actually impacted the daily routines of the regular citizen during the latter half of the nineteenth century. Architectural form carries social meaning that is easily read in its original cultural setting. In Japan, not only the position of the house within the city, but also the form and structure of the gateway and the material used to cover the roof were highly coded markers of status and heavily regulated during the Edo period 
(Coaldrake 1981). While the structure of the residential quarters remained mostly unchanged until the Great Kanto-Earthquake in 1923 and World War II, many might have experienced primarily western-style school buildings, barracks, hospitals, or administration offices. The buildings themselves were easily recognizable as non-Japanese at this time but beyond this probably incomprehensible in their intended meaning. It took time to translate the related social practices and to inscribe the initially foreign forms with Japanese meaning.

The building type most relevant here, the generic European and North American church model of the late nineteenth century, as it can be seen in all the Western urban expansions of the time, ${ }^{5}$ with its high-ceilinged, onestory longitudinal room and saddleback roof, steeple or ridge turret above the entrance, massive walls pierced by high windows, and often decorated with a pointed arch or Classical portico, was as different and foreign in Japan as the abovementioned new types of buildings that flourished during that era. That said, in each individual case in Japan, this common form of church-besides being shaped by liturgical considerations-was also naturally shaped by the regional, social and cultural background of individual missionaries, materials, and amounts of money available. What was introduced to Japan from Western culture in general to church buildings in particular were sets of cultural codes of homogeneous foreignness from the outside and high heterogeneousness from the inside. It was a moment in time that allows observing, in retrospect, the interrelation of change and perpetuation in religious contexts. In the Christian sense, tradition was

5 The nineteenth and early twentieth centuries saw a wide variety of formal solutions for church buildings in Europe and North America, in which historical styles, eclecticisms, and reformistic attempts imbricated. Yet the Gothic Revival model was the dominating form in discourse and the standard solution in urban development and especially in the context of mission, due to its perceived level of intrinsic spirituality (Germann 1974; De Maeyer and Verpoest 2000). 
kept by the mission projects themselves and the work of the individual missionaries. Yet the creation of new communities had a strong dynamic element that shifted not only the biographies of individuals as well as the built and social space of neighbourhoods, but the balance of a whole society. ${ }^{6}$ Furthermore, it shifted the meaning of the building form 'church'.

\section{Church Buildings}

Churches that have been preserved from that time or of which there is a visual or textual record mostly resemble Gothic Revival, Classical or Romanesque forms, even if built from wood. This took a conscious effort to achieve. The design ideas or plans were thought out from a western understanding of a building as a stiff and stable box made from (stone) walls. To realize this, the Japanese carpenters had to 'translate' spatial conceptions, structures, and decorations into Japanese structural principles of a skeleton construction of wood.

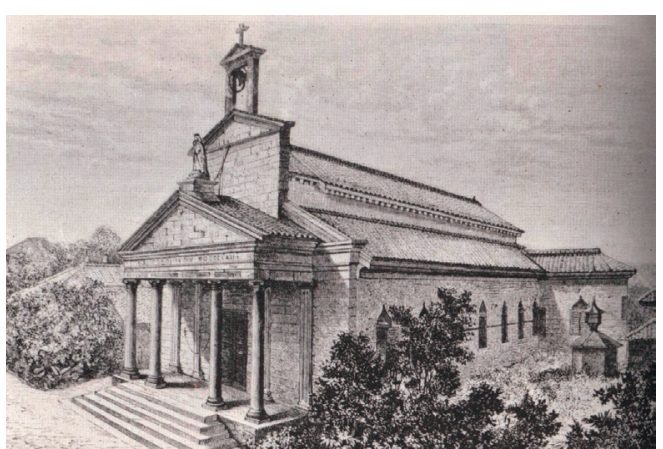

FIGURE 1
CATHOLIC CHURCH IN YOKOHAMA (1862, FR. PRUDENT GIRARD) (“NACHRICHTEN" 1876, 106)

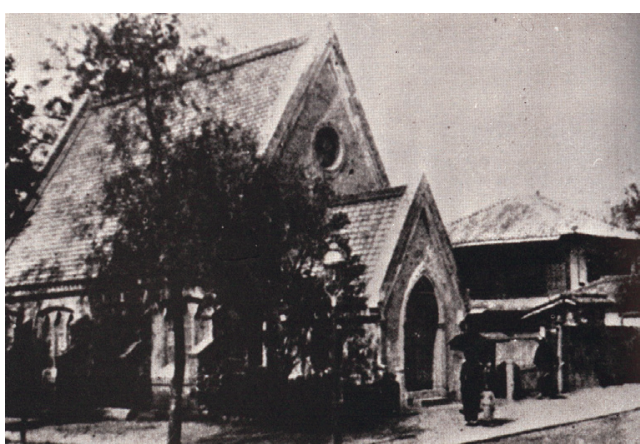

FIGURE 2 ŌURA CATHOLIC CHURCH (ŌURA TENSHUDŌ) IN NAGASAKI (1864, FR. LOUIS T. FURET, FR. BERNARD. T. PETITJEAN, HIDEYOSHIN KOJAMA) (MEID 1977, 37)

6 For a discussion of the dynamics of transformation and stability, see Stünkel 2017, 1. 
The Catholic Church in Yokohama was-as the other, following samplespart of an exterritorial settlement and served mostly the resident foreigner. It was erected by the French priest Prudent Girard in 1862 as a basilica with three naves. Built with bricks used as ballast in ships travelling to Japan, it featured small, pointed windows, a portico on four ionic columns, and a blind gable leading up into a belfry (Fig. $1^{7}$ ). Oura Tenshudō, the famous Catholic church in Nagasaki, also planned by French missionaries, and finished in 1864, fused Gothic and Baroque elements with a namakokabe façade, a Japanese surface covering from flat square tiles (Fig. 2). This church was initially in the form of a basilica with three naves; it had a solid basement and three towers above the entrance. Ōura Tenshudō was remodelled and enlarged to five naves soon after and suffered damage in 1945, but has been largely preserved in substance (Meid 1977, 110-111; Kojima 1992, 237-239, 312; Löffler 2011, 67-69). The

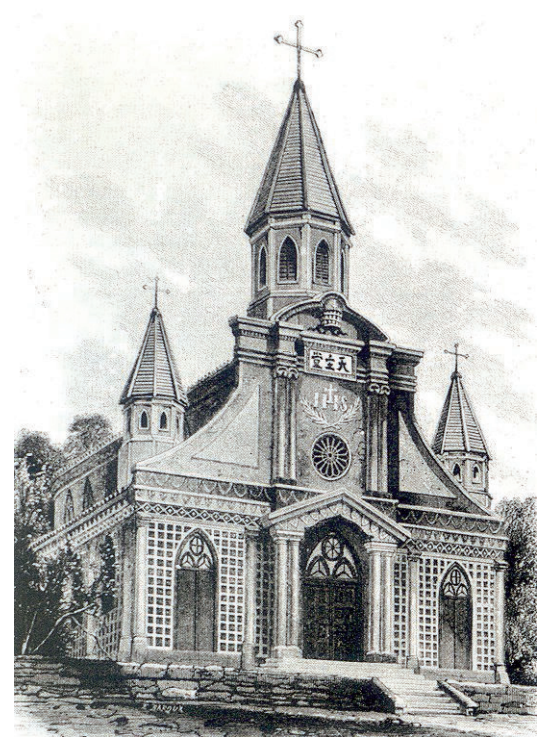

FIGURE 3 ANGLICAN-EPISCOPAL CHURCH IN OSAKA (1872/73) (MEID 1977, 54) in 1872-73, also using ballast bricks. The hall had a single nave, featuring buttresses, blind arches, and a small porch (Fig. 3).

During these early decades, quite a number of communities were initially not able to afford a separate building or even a room exclusively designed and used for worship; they utilized re-purposed secular buildings. While some communities with a Puritan background later went on to choose 
very plain design solutions, all church buildings traceable from this time show a significant use of 'churchy' architectural forms, or at least a spatial configuration of the interior that marks the space as special. ${ }^{8}$

Some of the abovementioned early churches of the 'hidden Christians' in the Nagasaki area fused western design with elements of Japanese building traditions in a much more obvious way. The church of St. Paul Daimyōji, erected in 1879 and later translocated to the Meiji-Mura Architectural Museum, resembles a Japanese farmhouse with a tiny bell tower atop the entrance. Its interior, however, follows the model of a stepped hall with three naves, its decorum inspired by Gothic Revival designs. The Japanese carpenter Ōto Isekichi, who had worked at Ōura Tenshudō a decade earlier, was responsible for designing this church and aimed to transfer and

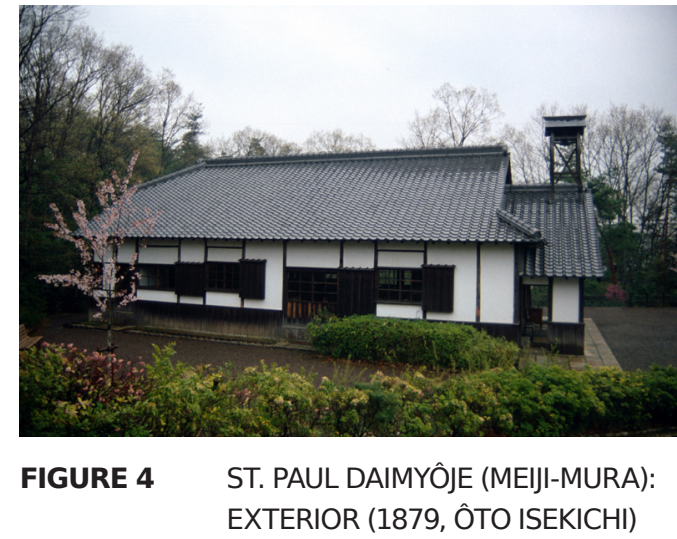

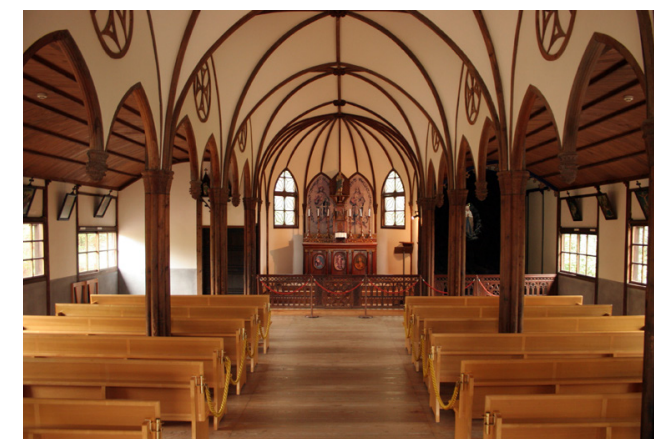

FIGURE 5 ST. PAUL DAIMYÔJE (MEIJIMURA): INTERIOR (1879, ÔTO ISEKICHI)

8 There are exceptions. First, there are some Christian denominations in Japan today that intentionally abstain from the notion of a dedicated room for worship, especially the indigenious Nonchurch Movement. Second, in some cases of very small communities, space for worship is not affordable even if desired. Thirdly, for some communities based on traditions such as those of the Mennonites, the places of worship are conceptionally not seen as special. Thus the attention given to them lies not in architectural forms but social narration and shared experience alone and needs to be analyzed based on interviews and liturgical teachings. 
integrate forms and spatial experience (Misawa 2000, 223; Löffler 2011, 69-71; Fig. 4, 5).

Most significant beyond this is the use of a genkan entrance that can be found in a number of other churches in the region as well. The genkan is the entry to a traditional Japanese house: a porch containing an earthen floor and a raised wooden section for removing shoes before entering the main level of the elevated building. While halls and rooms for secondary

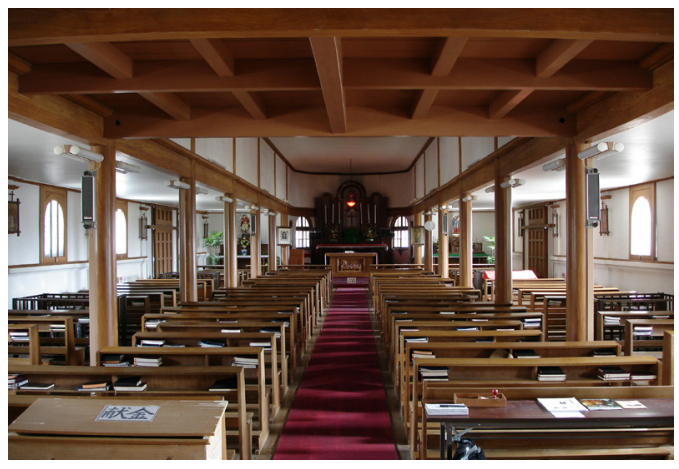
FIGURE 6
SHITSU CHURCH (NAGASAKI PREFECTURE), (1882, FR. MARC M. DE ROTZ)

use, such as storage, had wooden flooring, the flooring of living quarters in a traditional Japanese house was made out of tatami, panels of compacted straw and woven grass. ${ }^{9}$ This structural decision did not impact the proportions of St. Paul Daimyōji with its high ceiling, but it did impact those of Shitsu Church, 1882. This church was originally designed for the use with tatami, as to allow sitting directly on the floor during bible class and worship, and had the appropriate building height for this. With today's wooden flooring and pews, the ceiling is uncomfortably low (Fig. 6). Beyond this spatial impact, the use of genkan influenced the accessibility of the church interior. The need to take of one's shoes before entering emphasizes the threshold between the spheres of exterior and interior, public and private, and in this case even between immanence and transcendence (e.g. Shimada 1994).

9 In modern buildings, the function of genkan is performed by an area with tiling or synthetic flooring, separated by a small step from the raised wooden flooring. For detailed information, see http://www.aisf.or.jp/ jaanus/ [07.12.2018]. 
The spread of Christian communities was made easier by the constitution of 1889, which for the first time granted freedom of belief within certain limits, and created a framework for interaction between Christian communities and authority. But while confessional schools and hospitals-associated with western Christians-became an integrated part of social life, the status of Japanese Christians continued to be socially disputed (Ballhatchet 2003, esp. 36).

This paradox is probably rooted in two main factors: the legal and social status of Westerners in Japan, on the one hand, and the issue of Japanese national identity and patriotism, on the other. Between the first bilateral contracts from the 1850s and the new trade contracts of the mid 1890s, resident citizens from the West possessed specific status. While their residency was formally restricted to small areas, the exterritorial settlements, and travel was limited by passport regulations, ${ }^{10}$ they were exempt from Japanese law and thus free to exercise their faith (Perez 1996). It might also have been of relevance for the Japanese government's perspective that Christian faith was understood as an integral part of western culture. At the same time, the schools and charitable institutions with more or less visible Christian orientation played a significant role in the training of the next generations of Japanese leaders and the development of modern Japanese institutions.

The situation for Japanese Christians was different, due to ambiguity in Japanese perceptions of the religious and social properties of the teachings. On the one hand, Christianity was perceived as a philosophical system that went along with a specific way of thinking which had furthered the development of western cultures to its leading or even hegemonic role

10 The limitations were soon circumvented whenever desired or needed (Toyosawa 2008, 143-146; Bird 1881, 1: 84). 
in global power relations. On the other hand, Christian faith was seen as fundamentally problematic in the Japanese context or became conceptually problematic in the course of political reordering and the restructuring of responsibilities of the organs of the nation state. The core problem was that the profession of Christian faith implied ideas of belonging and loyalty that competed with traditional Japanese relationships within the family, to social or professional superiors, and to the overall public. On the individual level, it challenged the legal dominance of the patriarch under the newly reformed family law. On a general level, the monotheistic ban on practices from other religious contexts conflicted with the syncretistic religious system und broke with the common rites of passage as well as with the yearly calendar of festivals-both defining parameters of cultural belonging and social cohesion.

All this became even more complex with the growing governmental preference for shintō over Buddhism, which aimed to strengthen the role of the Emperor as head of state as well as spiritual leader of the nation. While this approach was argued for along the lines of filial piety and citizenship, the rites used in honoring the Emperor resembled Christian forms of worship. This created a moral conflict for some Christians, such as the teacher Kanzo Uchimura, whose short reluctance in 1891 to bow in front of an image of Emperor Meiji created a significant scandal, revealing mistrust of Japanese Christians and calling into dispute their patriotism (Ion 2003, 82; Ballhatchet 2003, 36-38; Zöllner 2006, 236-238; Hori 1963; Kitagawa 1961). Against this background, the development of church communities and the erection of churches was embedded within an intense fabric of adaptions and interpretations. This need for adaptation and interpretation applied not only to Japanese Christians but to missionaries, as well. Many of the chronicles and reports that remained from this time allow insight into 
the negotiation of ideas and concepts, be it Western / Japanese, Christian / non-Christian or liturgy / church building.

The sources on missionary architects and their design ideas are scarce, but the two most active left some textual sources. The American William M. Vories (1880-1964) received the call while attending the Student Volunteer Movement for Foreign Missions (SVM) in Toronto in 1902 and was sent as language teacher cum missionary to Ōmihachiman (Shiga Prefecture) two years later. Besides his many missionary and charitable activities, Vories started an architectural office that has built about 190 churches for Protestant communities across Japan until today (Vanderbilt 2005; Yamagata 2008; Löffler 2011, 192-193). Karl Freuler (1912-2000) was a Swiss priest of the Societas Missionaria de Bethlehem (SMB), trained for mission in China. Fleeing from his post in northern China from the People's Liberation Army, he arrived in Japan in 1948 and soon started planning churches for Catholic missionary organization to compensate for the buildings lost during the war or those needed for newly formed communities. He left for Switzerland in 1968, having planned 127 church buildings in Japan, Korea, and Taiwan (Brentini 1992; Holenstein 2004; Löffler 2011, 211-212). Both missionary architects struggled to find fitting architectural forms for the representation of the Christian faith in Japan. They expected western-style churches to be an interim and to be replaced over time by an indigenous Japanese expression of Christian architecture, which would be fed by the growing self-confidence of Japanese Christians and their growing knowledge about, and trust in, their faith. This did not exclude the architect's responsibility to communicate the art of church architecture accordingly until then (Vanderbilt 2005, 325-326, 353-355 and 358; Freuler 1950, 7-9; ibd. 1959, 54-56). This perception is shared and contextualized by architect and writer Justus Dahinden in 1966, although 
his argumentation shows a problematic concept of culture and civilization (Dahinden 1966, 31-32 and 43-45; Flemming 1937).

In contrast to these expectations and despite the growth of Japanese nationalism and attempts by the government to keep the different forms of religious life in check during the 1930s, however, the reliance of Japanese churches on imported architectural forms continued, even when existing buildings had to be replaced. Established design models were conserved as much as possible and often copied, occasionally
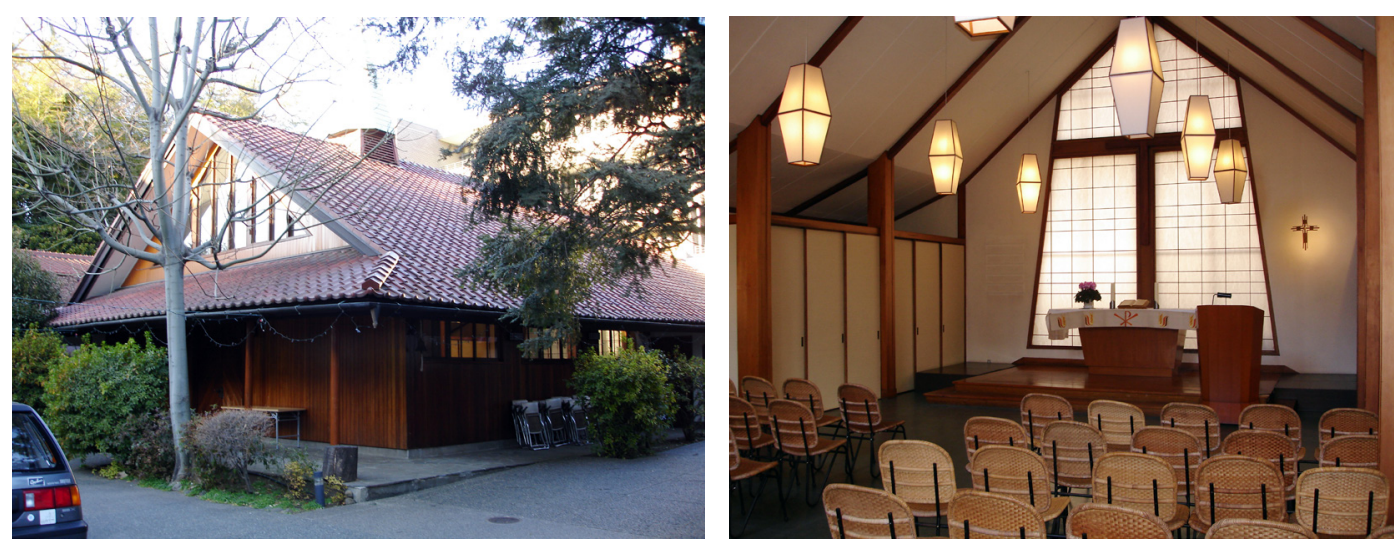

FIGURE 7+8 LUTHERAN CHURCH OF THE CROSS IN TOKYO-GOTANDA (1959, KONRAD WIESE)

even among local communities, regardless of denomination. This points towards the conclusion that the building form itself and its architectural style had become a visual code enriched with specific meaning within the communities, which Japanese Christians strove to maintain.

In parallel, attempts to create any form of visual Japanese-ness rooted in native building practices and forms for places of Christian worship were largely rejected by the Japanese faithful as unsuitable. Nationwide, there are just some dozen examples of visually Japanese churches among more than nine thousand churches and chapels overall. Most of these were built 
by well-meaning or romantic foreigners, like the German Konrad Wiese, who designed the Lutheran Church of the Cross in Tokyo in 1959 (Fig. 7, 8). ${ }^{11}$
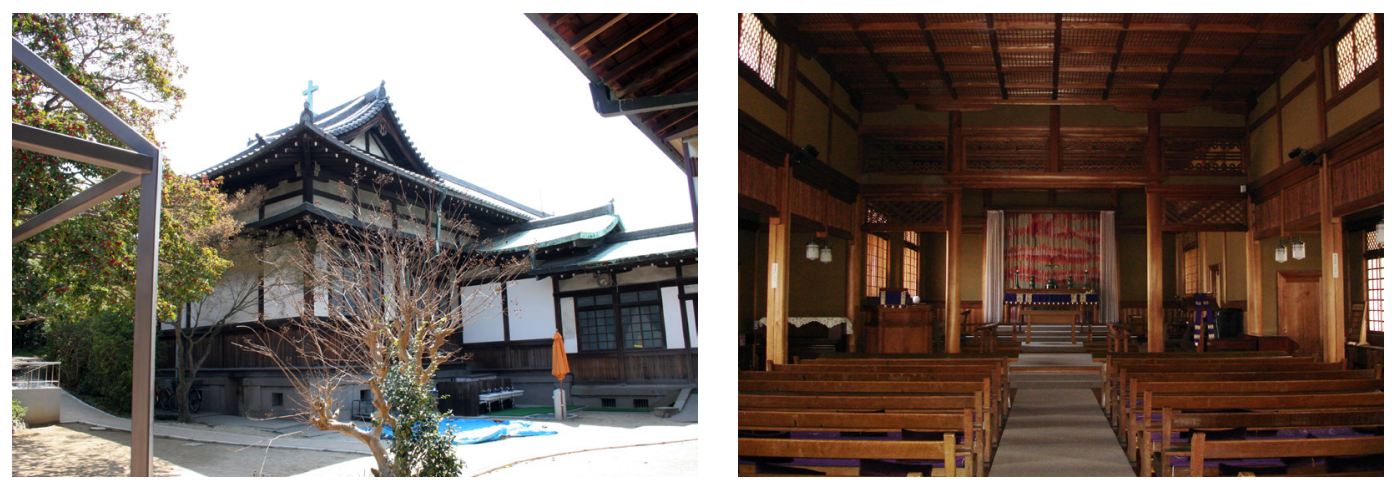

FIGURE 9+10 ANGLICAN-EPISCOPAL CHURCH OF THE CHRIST IN NARA (1930, KICHITARO OKI) (FIG 9. COURTESY OF MR. MARTIN FEILER, BASEL)

A very rare example and a special case is the 1930 Anglican-Episcopal Church of the Christ in Nara (Fig. 9, 10). The building features a skeletal structure and plastered infill of walls and a curved, half-hipped roof with decorative tiling above a cross-shaped floor plan. With the architectural forms referring to the nearby structures of Kōfuku-ji (eighth century, remaining buildings twelfth to seventeenth century), it was intentionally designed to integrate seamlessly into its built environment so as not to disturb the overall character of Nara's religious heritage sites. The nearby Catholic church, which followed a similar design of integration, has not been preserved.

Even after World War II, when Christianity received another boost in Japan and many churches were erected or rebuilt, these kept the traditional American or Central European designs of earlier decades or adopted the

11 Notes from a meeting with Ms. Hübler-Uemoto, Pastor of the German-speaking protestant community, Tokyo-Gotanda, 25.01.2006, confirmed by Katerine Tegtmeyer Pak, political science scholar and missionary's daughter during discussion at ADI conference, Copenhagen 2010. 
solutions of contemporary European reform, as Karl Freuler used them. Among new buildings, the dominance of formal eclecticism was eventually replaced during the 1960s and 1970s by mostly faceless modern concrete structures. ${ }^{12}$ Overall, however, traditional features, like towers or ridge turrets, saddleback roofs, and multi-story rooms, remain the dominant aesthetic form to this day (Fig. 11). Despite a handful of outstanding examples of modern form and space, Gothic Revival remains the most widespread influence on the design of Japanese churches to date.

This is to be understood in architectural terms alone and not to be mixed with the discourses on Gothic and Gothic Revival architecture in Europe and the western sphere. There, spiritual concerns motivate the continuation, completion, and, occasionally, the completely new construction of Gothic churches from the nineteenth to the twenty-first centuries. These projects are understood to continue and revitalize long-lasting traditions to foster belonging and social coherence (e.g. Klein 2008), thus supporting the definition offered in the Käte Hamburger Kolleg Dynamics in the History of Religions Between Asia and Europe Working Paper on tradition (Krech and Karis 2017, 1). In contrast, the Gothic Revival style of Japanese churches stands neither for spiritual belonging nor for a temporal bridging between continuity and discontinuity along the lines of the European tradition. The apparent tradition is rather a formal image or topos. It serves as a marker of modern Japanese Christian religious identity that highlights the existence of a community united in faith and sets these communities apart from the non-Christian majority by utilizing visual otherness ${ }^{13}$, formal nonJapanese-ness.

12 Exceptions and special cases are the World Peace Memorial Cathedral in Hiroshima by Tōgo Murano, 1953 and St. Mary's Cathedral in Tokyo by Kenzō Tange, 1964.

13 With this term I refer to the generic distinct other at the root of constructing identity; e.g. the person, group, practice, language, or idea that is not part of one's own identity but 
Over time, this set of architectural forms most probably lost the initially significant meaning of non-Japanese-ness from the years of mission and shifted into or was enhanced by a meaning of a specific kind of westernness or even of belonging to modernity in general. On a second level, the re-occurring use of Gothic Revival forms created a Japanese Christian tradition of inscribing references in earlier buildings in the same community or to the Christian presence in the area. This said, the initial formal otherness became deeply intermingled with different parts of Japanese
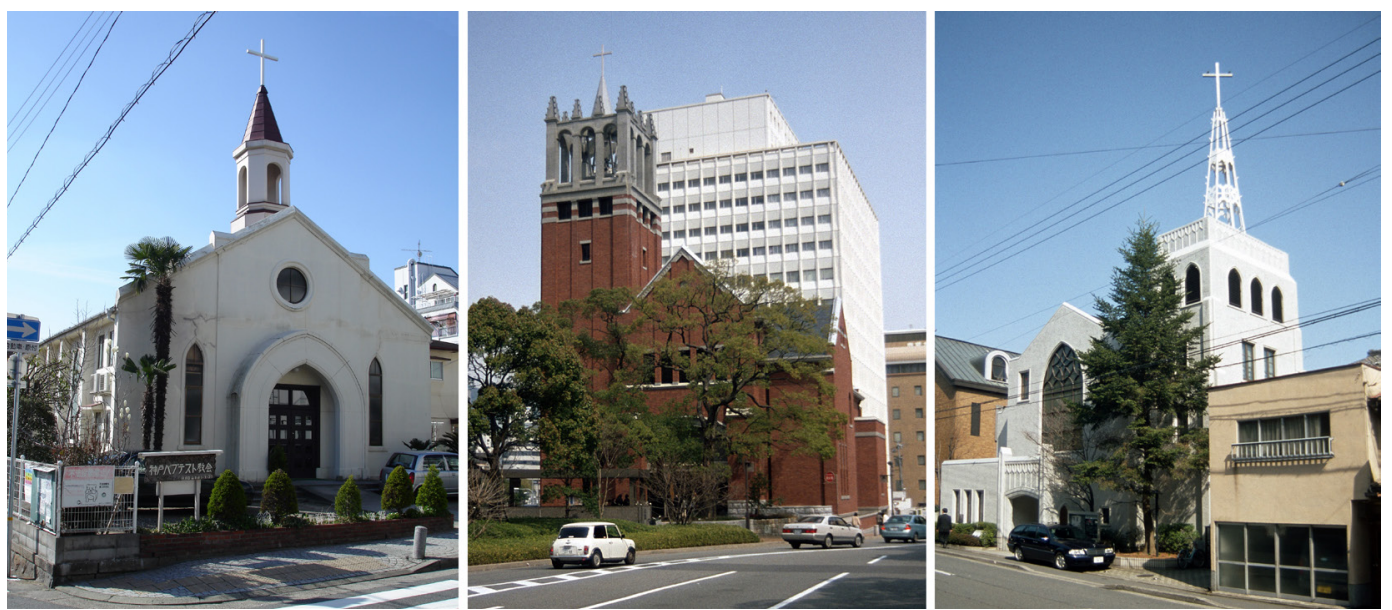

FIGURE 11 “CHURCHLY” CHURCHES IN JAPAN: BAPTIST CHURCH IN KOBE (1953), EIKO CHURCH KOBE (2004), RAKUYO CHURCH IN KYOTO (1988)

society: For the Christian communities, the form of the church building represents their local presence as a religious group and their belonging with the faithful of earlier generations as well as with parishioners today. In some cases, it might even be understood as a reference to ecumenism

essentially needed to create a sense of self and belonging by differentiation. I do not refer to the more complex understanding of otherness as Homi Bhabha uses it in discourses on cultural identity and orientalism, but it does no harm to remain aware of these issues in cross-cultural research. 
or the institutional roots of Christianity in Europe. ${ }^{14}$ All in all, the form of the church became a marker of tradition, of stability in time and belonging, against the background of ongoing dynamic adaptations.

The significant, iconic form of the Christian church with its non-Japanese architectural characteristics has been part of the symbolic repertoire of Japanese places of worship for decades, distinguishing Christian communities from adherents of Buddhist or Shintoist practices, and has not been questioned by Christian communities, non-Christian society, or the government. Even in the 1930s, when Christian social networks often came under government supervision because they were suspected of subversive activities, church buildings in themselves were not viewed as representing any form of authority, as they would have been in a monotheistic environment. ${ }^{15}$ The church building was implanted in Japan as a built form, an architectural image, at the same time as religious teachings gained a foothold. However, the teachings and architectural forms became acculturated not entirely separately but differently. And in this course, some of the meanings attributed to Christianity and Christian churches in Europe were ignored or omitted.

14 Japanese texts on church design are rare but all include a recourse to the European history of architecture and the established forms of church architecture (Kenchiku Shichō Kenkyūjo 1992; Tabuchi 2006).

15 I know of only two cases in which the church building itself became a matter of (political) discussion. There is the Orthodox Holy Resurrection Cathedral in Tokyo, 1891, which caused critique by its topographical position. Situated on a slope, it not only towers higher than the imperial palace (which had lost its enormous main keep centuries earlier to fire), but provided views into the area until, over time, other buildings obscured it (Ballhatchet 2003, 52-54; Huddle 1956, 54-58 and 61). In Kyoto, the Anglican church of St. Agnes, 1898, is situated just west of the Imperial palace. It initially exhibited a stained glass window in its eastern choir façade, which was relocated to the southern side of the choir when the Imperial family complained (Löffler 2011, 82). 
The Christian church building in Europe has an historically accumulated symbolic meaning of identity, transcendence, political and legal power, and the like inscribed that intermingles inseparably with its architectural form and is, even today, part of social reality, as e.g. in the cases of church asylum or the discourses on conversion or destruction of neighborhood churches. While this embeddedness of religious and profane meanings is often understood as a self-evident part of Christianity, it did not develop in Japan in the same way. The communities took the architectural form as a stable frame of reference and filled it with the adapted meanings and functions of a comparatively young religious minority. The focus of remembrance and narration is on people and the development of the community itself, rarely on the church building. Even the communities that take special pride in their places of worship due to their specific beauty or antiqueness do so subordinated to person-related issues (Löffler 2011, 161190 and 243-249).

Seen from the perspective of architectural analysis, this had two consequences: On the one hand, the fact that form and teaching took root separately and without most of the layers of European cultural attributions created a leeway, a space of negotiation of meaning, that was filled with explicitly Japanese expressions of religious practice and belonging, resonating as far as possible in the social parameter of modern Japan. While the shell of the church buildings remained steadily 'other' and the internal spatial function was adapted, Christian communities very quickly became firmly Japanese, making Japanese Christians a well-integrated religious minority. They supported the political development of Japan to a large extent and became socially active, whether in pastoral work among the Russian prisoners of war in 1904/05, in Christian mission in the occupied territories on the continent and in South-East Asia (Ion 2003), or-after World War II-in peace work and ecumenism. This embeddedness in the 
overall social structure allowed, on the other hand, another process of appropriation to take place within the non-Christian majority. It made the Christian church building a template for romantic experience and marital belonging: the wedding chapel.

\section{Wedding Chapels}

As early as during the latter half of the nineteenth century, as soon as the extraterritorial settlements were established and modernization was underway, not only did Christian missionary activity begin, but so did the propagation of western morals. Both issues were historically deeply connected, but the development of modern nation states influenced by Enlightenment had led to a certain detachment of some topics from the realm of religious teachings and their integration into the responsibility of state institutions. Thus, topics like public health and hygiene, moral education, temperance, as well as marital fidelity and the equality of the sexes within marriage were not just discussed in a religious context, but on a general societal level as well.

In the course of the Meiji reforms, Japanese family law became aligned with western concepts such as monogamy and primogeniture. This strengthened the decision-making role of the head of the family and the role of marriage as an exclusive and lifelong relationship. The wedding, which had traditionally only involved families and their immediate social environment, became embedded in the social fabric of the nation state and was enhanced by a formal shintō rite (Hendry 1981; Shimada 2000, 5963; Goldstein-Gidoni 1997; Naito 2001). With the wedding of crown prince Yoshihito (1879-1926, Taishō Tennō) in 1900, the rite became popular in the upper classes (Smith 1995, 28). 
During the 1920s, cities like Tokyo and Osaka experienced a metropolitan entertainment culture in a constant process of cultural negotiation with developments in London, Paris, or New York as well as the ensuing social shifts. The widely available print media promoted the concepts of equality in marriage and the nuclear family, thus providing new role models. This did not have an immediate impact, since the political agenda aimed to align all social structures to the national state and hindered the independent development of nuclear families. However, these ideas were revisited after World War II, when economic growth in Japan raised the standard of living and created a middle class with single-earner households. Weddings became a social event, for which first novels had provided narrative background before cinema-and later television-showcased romantic role models (Goldstein-Gidoni 1997). Here, the media played a crucial role as an agent of social ideas intermingled with religious content, such as church buildings, clerics, worship and other ritual (Karis 2017). It was also intentionally used by the imperial family, which, again, promoted the shift in wedding practices. In 1959, crown prince Akihito's (*1933) wedding with Michiko Shoda (*1934) was broadcast on the radio, their courtship the first imperial love match which was widely known about due to newspaper coverage. Shortly afterwards, the well-known Japanese actors Yujiro Ishihara (1934-1987) and Mie Kitahara (*1933) married, drawing special attention when the bride wore a white western wedding dress with veil at the reception. ${ }^{16}$

Many movies added to this, the most popular and influential probably being The Sound of Music in 1965. It told the Cinderella story of an orphan girl entering the household of a noble widower with many children as a

16 See the upper right image at Stā no kekkonshiki [Star's wedding] https://blogs.yahoo. co.jp/frontegcw/40752055.html [04.12.2017]. 
nurse and governess and ending up the new wife. ${ }^{17}$ Over time, romantic love became connected with fairy-tale weddings and the bride as a princess-fora-day, as in the star union of popular singer and actress Momoe Yamaguchi (*1959) and actor Tomokazu Miura (*1952) in 1980 (Buruma 1984, 4546; Brasor 2011). The live-broadcasted wedding of British crown prince Charles (*1948) with Lady Diana Spencer (1961-1997) in 1981 boosted this idea even more and finally kicked the market for western-style weddings into gear (Ōbayashi 1997; LeFebvre 2015; Drazen 2017). Over time, not only wedding dresses and cakes embellished the celebration of marital bliss and the establishment of a new Japanese nuclear family, but specific rooms appeared to provide an appropriate setting for the ceremony of the vows. ${ }^{18}$ These were embedded into the premises of establishments that catered for weddings, initially indoor, later as detached buildings as well (Fig. 12, 13). Hundreds of secular wedding chapels mushroomed in Japan, providing movie-like settings for ceremonies and receptions and giving the architectural form of the Christian church a new and secular meaning as a place of marital belonging. ${ }^{19}$

What happened here was architecturally a similar phenomenon as with the community churches: the adoption of the stable image of the built shell, the church building, and the highly complex and dynamic reinterpretation of its function. This is not so much a process of de-sacralisation as an image-

17 Directed by Robert Wise, with Julie Andrews, Christopher Plummer; Twentieth CenturyFox/Argyle Enterprises, 1965. For a number of reasons, the movie had no impact in the German speaking countries and its worldwide success went mostly unnoticed. It was however influential in the perception of Austria and resulting tourism (KammerhoferAggermann 2000).

18 It is important to remain aware that the legal part of the marriage, conducted with the local administration, and the here discussed celebration are separate events, often taking place months if not years apart from each other (Goldstein-Gidoni 1997).

19 See e.g. the Bellclassic compound in Kobe https://www.bellclassic.co.jp/kinki/kobe/ [01.03.2018]. 
transmitted and narration-transmitted creation of a new tradition from other lines of tradition: The Christian church as an established institution of
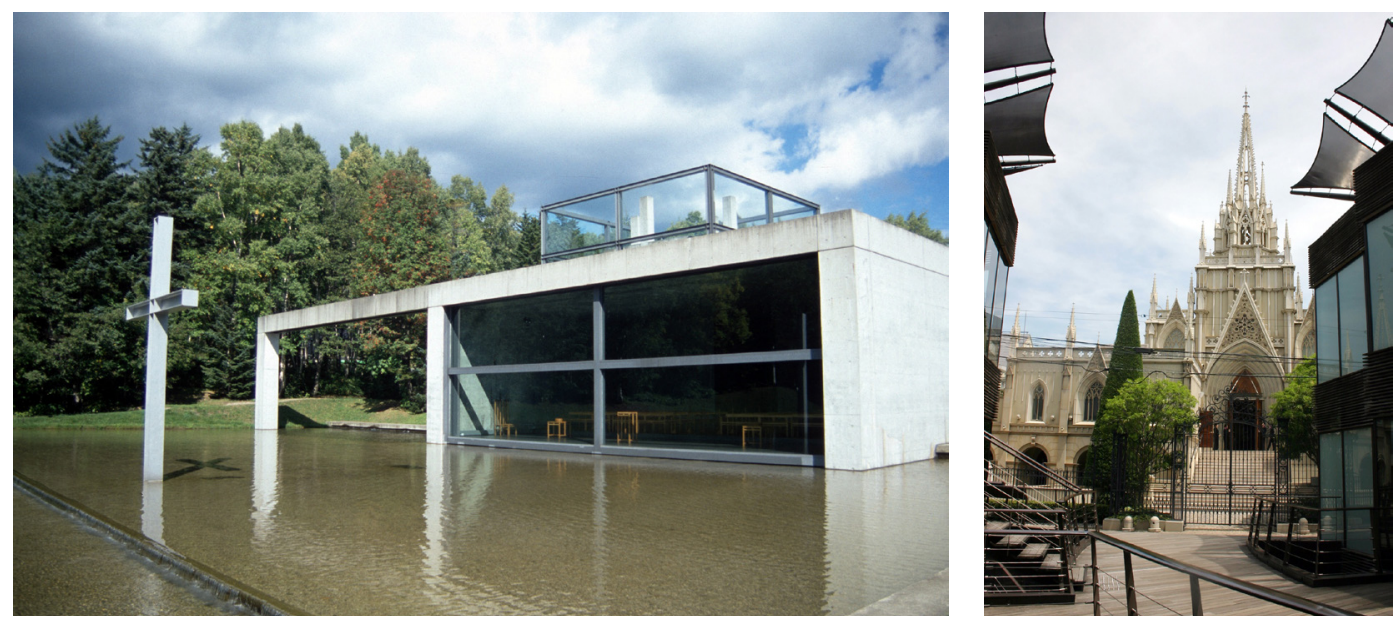

FIGURE 12 CHURCH ON THE WATER IN TOMAMU (HOKKAIDO) (1988, TADAO ANDO)

FIGURE 13 ST. GRACE CATHEDRAL TOKYO-SHIBUYA (2006)

legal marriage, the Western practice of White Weddings, the Western idea of romantic love and the Japanese tradition of marriage as a rite of status representation came together. Ultimately, when considering religious entanglements, this is fascinating less in terms of contact between Christianity and Japanese religions and more in terms of contact between Western Christianity and its own image, reflected by secular practices of romance. Until today, the majority of weddings chapels is located indoors and, thus, withdrawn from public spatial interaction beyond the crowd visiting at wedding fairs. Here, the spatial characteristics are primarily reproduced and multiplied by wedding albums and films, in the course of sharing the experiences and memories of wedding ceremonies with family and friends. However, the number of detached wedding chapels in urban spaces is extensive enough to draw attention and to erroneously 
'recognize' the buildings as parish churches, not least because the detached wedding chapels started, formally speaking, exactly were the churches had left off: with a preference for Gothic Revival. The solutions include box-like buildings with gabled roofs and small ridge turrets on the edges of a parking lot, similarly simple buildings positioned on the roof terraces of the respective hotel or wedding business, and ambitious chapel designs in landscaped holiday resorts or exuberantly decorated ensembles of chapel(s) and auxiliary buildings claiming an entire city block. Between the vast majority of eclectic buildings with an ongoing use of Christian symbols, a small number of decidedly modern designs exceed the frame of marketable consumerism into discursive architecture, on the one hand, and nature as symbolic reference of transcendence, on the other (Löffler 2019).

It was this small group of modern buildings that raised awareness in the West for the growing importance of churches and wedding chapels in Japan, and sometimes resulted in the false understanding that these building were, in fact, churches. In this sense, the influence of Western architecture was reflected back to the West. Since most of the wedding chapels are of small size and use historic forms well-known from Christian church architecture in Japan and elsewhere, the phenomenon was long ignored by architectural discourse. It was only with Tadao Ando's works from the late 1980s and 1990s that the field took notice. With their modern forms in alignment with architectural icons like Gunnar Asplund's (1885-1940) Woodland Cemetery near Stockholm (1917-1940), the buildings were easily readable as offspring of Christian religious architecture. Consequently, Ando's two wedding chapels and one community church became recognized and equally acknowledged as prime examples of modern Church architecture. The fact that not all of them were actually churches, some only built in the form of churches, went largely unnoticed. Again, only the image of a building became transferred, not its religious meaning or absence thereof. 
(The conceptual and liturgical differences between the building types were noticed and discussed in Japanese Studies, but never overcame the disciplinary divide into architecture, not even in Japan.) Despite that fact, or perhaps precisely because of it, the published Japanese designs-churches and wedding chapels alike-re-inspired designs in the West with their often consequent modernity of form and/or material. ${ }^{20}$

The idea of a consequently romantic chapel wedding gained foothold in Korea and China as well, bringing forth new and even more creative solutions of staged space and architecture. By now, the idea has made it back to Europe, where the first fully secular wedding chapel in Germany started business in Callenberg on December 22, 2017 ("Hochzeitskapelle" 2017).

\section{Conclusion}

The transfer of western religious and architectural concepts to Japan since the latter half of the nineteenth century (re-)started cultural encounters and processes of acculturation, adoption, and re-interpretation both in Japan and the West.

Christian belief and ethics found their way into modern Japanese society via charismatic leaders as well as religious, educational, and welfare institutions, on the one hand, and via popular culture, on the other. Literature and print advertisements, movies, commercials, and television

20 It is interesting to notice that the economic background of the issue remains undiscussed so far, even though it constitutes a crucial factor of ambitious architecture, especially regarding places of worship. Tadao Ando explained his design of the Church of the Light partially with the financial shortage of the contracting community. However, the topic was never raised regarding his other buildings or similar projects, which are often much more representative. 
series communicated western lifestyle and shaped the idea of modern life-even if it was often challenged and questioned over against the understanding cultural identity and Japanese tradition. In the entanglement of different traditions and social models, Christian mission became a trigger for a highly dynamic negotiation of religious and secular ideas and ideals of identity.

In terms of architecture, the transfer correlated with a significant rupture of traditional patterns. The highly coded form of the Christian church building in European tradition with its shape, spatial positioning, and formal significance as a location of power was not passed on to Japan. Besides the religious content, the 'image' of a building with a steeple and certain accompanying features was passed on and laid the foundation of a new building tradition. Christianity's status as a religious minority freed it from larger socio-political implications. The church buildings became part of the style inventory of neither the modern national state's architecture nor of any institution of state religion, as happened at least partially with shintō. The churches are special designs: formally close to traditional European models but of 'private' character within the built environment, they do not easily connect formally to the neighbourhood ${ }^{21}$ or a specific denomination. This floating character initiated the creation of a second tradition, the wedding chapel. Again, the 'image' was adopted and reinterpreted to answer Japanese needs. Here, the transfer occurred from one part of Japanese society into another and created an autonomous new tradition. As an architectural structure in an urban context, wedding chapels present-like Japanese church buildings-hermetic entities to a great extent. Their significant church-like form ensures easy formal

21 This seems to mirror the general urban role of Buddhist and Shintoist institutions, but there is more research needed to confirm the observation. 
recognition in principle but does not allow for social interaction within the neighbourhood.

In the end, the acculturation of Christian church architecture in Japan showcases the inconstancy of complex religious systems in transfer between regions and cultures. This allows for integration and adoptions and shows religious systems as highly adaptable entities.

\section{Literature}

Ballhatchet, Helen J. 2003. "The Modern Missionary Movement in Japan. Roman Catholic, Protestant, Orthodox." In Handbook of Christianity in Japan, edited by Mark R. Mullins, 35-68. Leiden: Brill.

Bird (Bishop), Isabella Lucy. 1881. Unbeaten Tracks in Japan: an account of travels on horseback in the interior: including visits to the aborigines of Yezo and the shrines of Nikkô and Isé, 2 vols. London: John Murray.

Brasor, Philip. 2011. "Mr. Momoe Yamaguchi finally decides to speak." The Japan Times (online), 11.12.2011. https://www.japantimes. co.jp/news/2011/12/11/national/media-national/mr-momoeyamaguchi-finally-decides-to-speak/\#.Wpefk6ImH I.

Brentini, Fabrizio. 1992. Karl Freuler. Architektur für die Kirche. Japan 1948-1968. Baden: Müller.

Buruma, Ian. 1984. A Japanese Mirror. Heroes and Villains of Japanese Culture. London: Penguin.

Coaldrake, William H. 1981. "Edo Architecture and Tokugawa Law." Monumenta Nipponica 36 (3): 235-284. 
Dahinden, Justus. 1966. Bauen für die Kirche in der Welt. Würzburg: Echter.

De Maeyer, Jan, and Luc Verpoest, eds. 2000. Gothic Revival. Religion, Architecture and Style in Western Europe 1815-1914. Leuven: Univ. Pers Leuven.

Drazen, Patrick. 2017. Holy Anime!: Japan's View of Christianity. Lanham: Hamilton Books.

Dumoulin, Heinrich. 1990. “Christentum.“ In Japan-Handbuch. Land und Leute, Kultur- und Geistesleben, edited by Horst Hammitzsch. 3rd. ed. 1377-1386. Stuttgart: Steiner.

Finn, Dallas. 1995. Meiji Revisited. The Sites of Victorian Japan. New York: Weatherhill.

Fisch, Michael. 2001. "The Rise of the Chapel Wedding in Japan: Simulation and Performance." Japanese Journal of Religious Studies 28 (1/2): 57-76.

Flemming, Daniel Johnson. 1937. Heritage of Beauty. Pictorial Studies of Modern Christian Architecture in Asia and Africa. Illustrating the Influence of Indigenous Cultures. New York, NY: Friendship Press.

Freuler, Karl. 1950. "Church Architecture in Japan." The Missionary Bulletin (Fall): 7-11.

- - . 1959. "Is Adaptation of Church Architecture a Misunderstood Ideal? Reflections of a Priest-Architect." Liturgical Arts. A Quarterly devoted to the Arts of the Catholic Church 27 (3): 5456.

Germann, Georg. 1974. Neugotik. Geschichte ihrer Architekturtheorie. Stuttgart: Deutsche Verlagsanstalt.

Goldstein-Gidoni, Ofra. 1997. Packaged Japaneseness: Weddings, Business and Brides. Honolulu: University of Hawaii Press. 
- - - 2001. „Hybridity and Distinctions in Japanese Contemporary Commercial Weddings." Social Science Japan Journal 4 (1): 21-38. Hecken, J. L. van. 1963. The Catholic Church in Japan since 1859. Tokyo: Herder.

Hendry, Joy. 1981. Marriage in changing Japan: Community and Society. London: Croom.

“Hochzeitskapelle-Medieninteresse ist ungebrochen." Freie Presse online, 21.12.2017. https://www.freiepresse.de/LOKALES/ ZWICKAU/WERDAU/Hochzeitskapelle-Medieninteresse-istungebrochen-artikel10084496.php.

Holenstein, Hans. 2004. Bethlehem Mission in Japan. 1948-2001. Immensee: Bethlehem-Mission.

Hori, Mitsuo. 1963. Kanzo Uchimura. Baumeister der ungebauten Kirche (Mukyōkai). Stuttgart: Junge Gemeinde.

Huddle, Benjamin P. 1956. "History of the Lutheran Church in Japan." PhD diss., University of Temple University.

Iglehart, Charles W. 1959. A Century of Protestant Christianity in Japan. Rutland, Vt. And Tokyo: Tuttle.

Ion, A. Hamish. 2003. "The Cross under an imperial Sun. Imperialism, Nationalism, and Japanese Christianity, 1895-1945." In Handbook of Christianity in Japan, edited by Mark R. Mullins, 69-100. Leiden: Brill.

Jennes, Joseph. 1973. A History of the Catholic Church in Japan. From its Beginnings to the early Meiji Era. Rev., enl. ed. Tokyo: Oriens Inst. for Religious Research.

Kammerhofer-Aggermann, Ulrike, ed. 2000. "The sound of music" zwischen Mythos und Marketing. Salzburg: Salzburger Landesinst. für Volkskunde. 
Karis, Tim. 2017. “Media.” KHK Working Paper Series IV. https://er.ceres. rub.de/index.php/ER/concepts.

Kenchiku Shichō Kenkyūjo Hen. 1992. Kyōkai-Kenchiku. KirisutoKyōkai, Shūdō-In, Gakuen. Kenchiku Sekkei Shiryō 36. Tokyo: Kenchikushiryōkenkyūsha.

Kitagawa, Daisuke. 1961. No-Church Christianity in Japan. A historical Assessment of its Significance to the missionary Movement. London: International Missionary Council.

Klein, Bruno. 2008. "Turmvollendungen gotischer Kathedralen im 20. und 21. Jahrhundert." In Himmelszeichen. 100 Jahre Meißner Domtürme, edited by Günter Donath, and Matthias Donath. 266275. Meißen: Ed. Sächsische Zeitung.

Krech, Volkhard, and Tim Karis. 2017. “Tradition." KHK Working Paper Series IX. https://er.ceres.rub.de/index.php/ER/concepts.

Kojima, Akio. 1992. Nihon no Kyōkai-dō. Sono Kenchiku-Bi to Hyōjō; Tokyo: Nihon Kirisuto Kyōdan Shuppan Kyoku.

LeFebvre, Jesse. 2015. “Christian wedding ceremonies: 'Nonreligiousness' in contemporary Japan." Japanese Journal of Religious Studies 42 (2): 185-203.

Löffler, Beate. 2011. Fremd und Eigen: Christlicher Sakralbau in Japan nach 1853. Berlin: Frank und Timme.

_-_. 2015. "The perpetual Other. The Japanese architecture in western imagination." International Journal for History, Culture and Modernity 3 (3): 83-112.

- - - 2017. "Petrified worldviews. Eurocentric legacy in architectural knowledge bases on Japan." InterDisciplines 8 (2): 69-95.

- - . 2018. "Importierte Heiligkeit. Christliche Raumkonzepte in Japan." In Heilige Orte und sakraler Raum in den Religionen Japans, edited by Michael Wachutka. München: iudicum (in print). 
——-. 2019. „Geborgte Heiligkeit, gebaute Romantik. Die japanische Hochzeitskapelle als auratischer Raum?“ In RaumkultKultraum. Architektur und Ausstattung in (post)traditionalen Gemeinschaften, edited by Anna Minta (in print).

Meid, Michiko. 1977. Der Einführungsprozeß der europäischen und der nordamerikanischen Architektur in Japan seit 1542. Köln: Kleikamp.

Misawa, Hiroaki, and Hideto Kawakami. 2000. Ōinaru isan: Nagasaki no kyōkai / A Great Heritage. Churches in Nagasaki. Tokyo: Tomoshobō.

Miyazaki, Kentaro. 2003. "Roman Catholic Mission in Pre-Modern Japan." In Handbook of Christianity in Japan, edited by Mark R. Mullins, 1-18. Leiden: Brill.

Mullins, Mark R., ed. 2003. Handbook of Christianity in Japan. Leiden: Brill.

Mullins, Mark R. 2003a. “Indigenous Christian Movements" In Handbook of Christianity in Japan, edited by ibid., 143-162. Leiden: Brill.

“Nachrichten aus den Missionen. Japan." In Die katholischen Missionen Mai 1876: 104-107.

Naito, Yuko. 2001. "The big day. Modern Couples seek to tweak the nuptial Norms." The Japan Times online. 05.08.2001. https:/l www.japantimes.co.jp/community/2001/08/05/general/the-bigday/\#.Wpfad6ImH_k.

Ōbayashi Taryō. 1997. “Der Ursprung der shintōistischen Hochzeit.“ In Rituale und ihre Urheber: Invented Traditions in der japanischen Religionsgeschichte, edited by Klaus Antoni, 39-38. Hamburg: Lit. 
Oshiro, George M. 2007. “Nitobe Inazō and the Sapporo Band: Reflections on the Dawn of Protestant Christianity in Early Meiji Japan." Japanese Journal of Religious Studies 34 (1): 90-126.

Perez, Louis G. 1996. "Revision of the unequal Treaties and Abolition of Extraterritoriality." In New Directions in the Study of Meiji Japan, edited by Helen Hardacre. 320-334. Leiden: Brill.

Shimada, Shingo. 2000. Die Erfindung Japans. Kulturelle Wechselwirkung und nationale Identitätskonstruktion. Frankfurt/Main: Campus.

Shimada, Shingo. 1994. Grenzgänge-Fremdgänge. Japan und Europa im Kulturvergleich. Frankfurt/Main: Campus.

Smith, Robert J. 1995. “Wedding and funeral Ritual. Analysing a moving Target." In Ceremony and Ritual in Japan: Religious Practices in an Industrialized Society, edited by Jan van Bremen. 25-37. London: Routledge.

Stewart, David B. 2002. The Making of a Modern Japanese Architecture, From the Founders to Shinohara and Isozaki. Tokyo: Kodansha International.

Stünkel, Knut Martin. 2017. “Dynamics \& Stability.” KHK Working Paper Series VI. https://er.ceres.rub.de/index.php/ER/concepts.

Tabuchi Satoshi. 2006. Kyōkaidō-Kenchiku. Kōsō kara Kendō made. Shinkyō Shuppan-sha.

Tagsold, Christian. 2017. Spaces in Translation: Japanese Gardens and the West. Philadelphia: University of Pennsylvania Press.

Toyosawa, Nobuko. 2008. "The cartography of epistemology: The production of 'national' space in late 19th century Japan." PhD diss., University of Illinois at Urbana-Champaign. 
Vanderbilt, Gregory Allen. 2005. "'The kingdom of God is like a mustard seed'. Evangelizing Modernity between the United States and Japan, 1905-1948." PhD diss. University of California, Los Angeles.

Yamagata, Masaaki. 2008. ヴォーリズ建築の100年一恵みの居場所をつくる (Vōrisu Kenchiku no hyakunen. Megumi no ibasho wo tsukuru. 100 Years of Vories Architecture: Creating a place of grace). Ōsaka: Sōgensha.

Zöllner, Reinhard. 2006. Geschichte Japans. Von 1800 bis zur Gegenwart. Paderborn: Schoningh. 